\title{
War against the COVID-19 pandemic: reflection in light of Florence Nightingale's nursing theory
}

\author{
Guerra contra a pandemia COVID-19: reflexão à luz da teoria de enfermagem de Florence Nightingale
}

Guerra contra la pandemia COVID-19: reflexión a la luz de la teoría de enfermería de Florence Nightingale

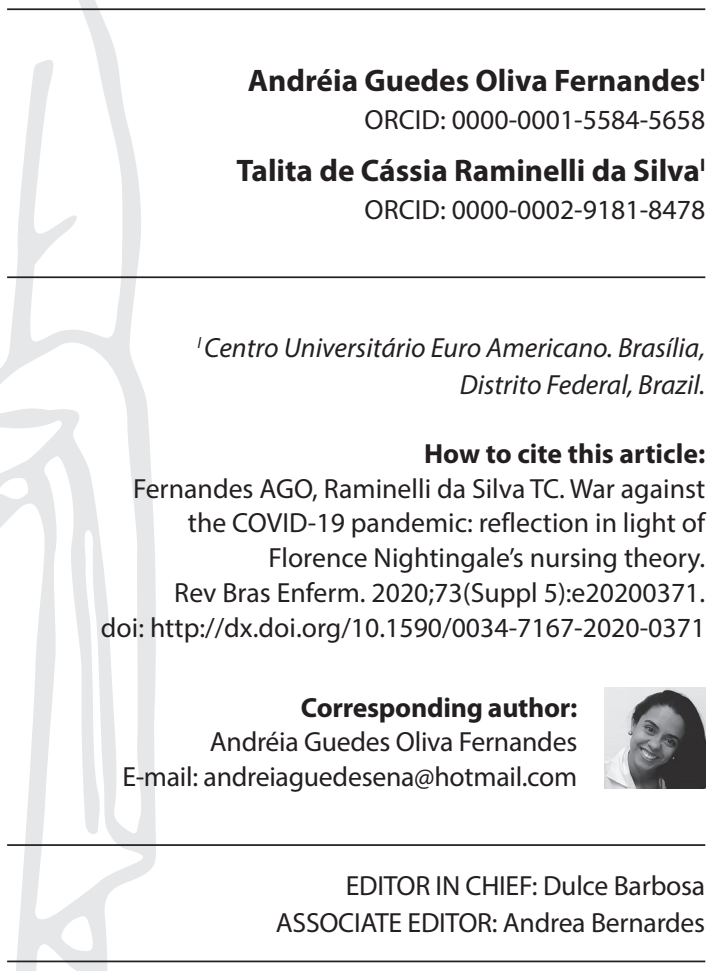

Submission: 04-29-2020

Approval: 06-29-2020

\section{ABSTRACT}

Objective: To reflect on the relationship and importance of the environmental theory regarding practices for promotion, prevention, and treatment of COVID-19. Methods: A theoretical-reflexive study about the COVID-19 pandemic in light of the environmental theory proposed by Florence Nightingale. Results: It is observed that the application of the theoretical foundations proposed by the environmental theory is related to the current practices used in the fight against the COVID-19 pandemic. Final considerations: It is believed that the theoretical basis is fundamental for the critical-reflexive training of the nursing professional, for the consolidation of Nursing as a science; therefore, it could provide a foundation in nowadays battle against the pandemic.

Descriptors: Nursing Theory; Environment; Nursing; Pandemic; COVID-19.

\section{RESUMO}

Objetivo: Refletir sobre a relação e importância da teoria ambientalista no tocante às práticas para a promoção, prevenção e tratamento da COVID-19. Métodos: Estudo teóricoreflexivo a respeito da pandemia da COVID-19 sob a luz da teoria ambientalista proposta por Florence Nightingale. Resultados: Observa-se que a aplicação dos fundamentos teóricos propostos na teoria ambientalista tem relação com as práticas atuais, utilizadas no combate à pandemia da COVID-19. Considerações finais: Acredita-se que o embasamento teórico é fundamental para a formação crítico-reflexiva do profissional de enfermagem, para a consolidação da Enfermagem como ciência; assim, ele pode fornecer alicerce no combate à pandemia na atualidade.

Descritores: Teoria de Enfermagem; Meio Ambiente; Enfermagem; Pandemia; COVID-19.

\section{RESUMEN}

Objetivo: Reflexionar sobre la relación e importancia de la teoría ambientalista en lo que respecta a las prácticas para la promoción, prevención y tratamiento de la COVID-19. Métodos: Estudio teórico y reflexivo a respecto de la pandemia de la COVID-19 bajo la luz de la teoría ambientalista propuesta por Florence Nightingale. Resultados: Se observa que la aplicación de los fundamentos teóricos propuestos en la teoría ambientalista tiene relación con las prácticas actuales, utilizadas en el combate a la pandemia de la COVID-19. Consideraciones finales: Se cree que el embasamiento teórico es fundamental para la formación crítica y reflexiva del profesional de enfermería, para la consolidación de la Enfermería como ciencia; así, él puede fornecer apoyo en el combate a la pandemia en la actualidad. Descriptores: Teoría de enfermería; Ambiente; Enfermería; Pandemia; COVID-19. 


\section{INTRODUCTION}

The disease classified as COVID-19, caused by the coronavirus named SARS-CoV-2, has spread rapidly throughout Brazil and the world. It started as an outbreak in one region of China and quickly disseminated to other continents, and now is considered a pandemic by the World Health Organization(WHO $)^{(1-2)}$.

The high transmissibility of this virus is recognized (by droplets, sneezing, coughing, secretions and contact with contaminated objects/surfaces/persons), which can cause different clinical spectra, characteristic of this disease, ranging from mild cases to more severe conditions, such as respiratory failure, and some cases evolving to death. Its lethality varies according to age range and associated clinical conditions $s^{(1-2)}$.

As a result of the symptoms, the physical consequences that the disease can cause and the preventive measures that have been adopted, such as social isolation, this pandemic marks a scenario of global crisis, which implies a series of problems, either for individuals, the families and/or communities, in various aspects of life ${ }^{(2-3)}$.

In such context, it is emphasized the importance of health professionals in minimizing the effects caused by public health calamity, especially nursing professionals, who are protagonists in the control of transmission of this disease and who are in the frontline in the fight against this pandemic, because they represent a greater number of health professionals and take care of the patients 24 hours a day ${ }^{(4)}$.

In the same way, it should be emphasized that the nursing staff seeks to perform in the set of actions aimed at prevention, treatment and rehabilitation at different levels of health care and the the nurse's job involves caring for people by meeting their individual needs. To this end, the profession consists of a mixture of science (base of knowledge) and art (skillful application of knowledge) ${ }^{(5-6)}$.

It is well known that nursing has advanced as theories arise, which represent the basis for nursing practice, and are important as questioning material for the profession to proceed in the discussion about nursing practice ${ }^{(7)}$. For example, it could be referred to the environmental theory created by Florence Nightingale. According to the theorist, several measures are related to the ambiance and impact on the health and disease process, and such observations are crucial for the current nursing practice ${ }^{(8)}$.

Be that as it may, for this reflection it was determined the following guiding question: What is the association and importance of the environmental theory regarding health action practices in promotion, prevention, and treatment of COVID-19?

\section{OBJECTIVE}

Reflect on the relationship and importance of environmental theory regarding practices in promotion, prevention, and treatment of COVID-19.

\section{METHODS}

This is a theoretical and reflective study on the COVID-19 pandemic, performed in April 2020, from the perspective of the environmental theory proposed by Florence Nightingale.
The focus of that theory is the environment, described by Florence as the factor that influences the health-disease process. The human being is understood as an integral being of nature, which is influenced by the healthy or unhealthy ambiance. The fundamental precept of the environmental theory is the maintenance of the vital capacities of the individual in order to satisfy his/hers basic health needs, and that is the role of nursing ${ }^{(9)}$.

\section{Actions to promote, prevent and treat COVID-19 from the perspective of the environmental theory}

Florence Nightingale developed the environmental theory whose focus was the ambiance, interpreted by a set of external conditions and influences capable of preventing, suppressing, or contributing to illness or death. It is recognized that a theory is composed of a series of concepts that describe a pattern of reality. In the case of nursing, the theory aims to describe the profession and thus provide the opportunity to develop better problem solving skills, offer the justification and knowledge necessary for nursing care, and increase the scope of knowledge of the profession by generating research that substantiates and improves practice ${ }^{(8-9)}$.

Considered the founder of modern nursing, Florence was the first nursing philosopher, and her experience in the Crimean War, in 1854, brought distinct teachings applicable in the current clinical practice of the profession. When analyzing the nightingale knowledge, one of the concerns of the theorist was with the patient's environment, regarding aspects related to cleaning, ventilation, humidity, clothing, temperature, lighting, odors, nutrition and noise which should be eliminated ${ }^{(7-9)}$.

It is noted that the same environmental factors cited by Florence have also been a source of concern for society in the face of the current pandemic scenario caused by the coronavirus (SARS CoV-2). This situation has brought changes in the daily life of individuals, families, communities and societies worldwide and has provoked changes in living habits, crucial for the implementation of preventive measures to combat the virus, such as the correct hygiene of hands regularly, maintenance of ventilated environments and avoidance of agglomerations $\mathrm{s}^{(1-2,4)}$. Equally necessary in the battle against the virus is the guarantee of a healthy diet ${ }^{(1-2)}$, another idea defended by the theorist, which reinforced the importance of a varied, nutritious and on time diet ${ }^{(8-9)}$.

With isolation and restriction of people's movement due to the pandemic, negative psychological effects such as anxiety, fear, insomnia, depression and stress have affected the population ${ }^{(3,10)}$. So, as Florence already emphasized, the environment influences the individual's general health status, because she understood that physical stress could affect the patient's emotional state and then suggested activities to keep the mind stimulated. She believed in a holistic approach directed at health and carried out actions involving the soldiers during convalescence in order to ensure the maintenance of health in the psychosocial dimension. This theorist approach coincides with the concept of health defined by WHO, according to which the physical, psychic, social and spiritual dimensions affect health ${ }^{(8-9)}$. 
It is important to point out that the health care prevention and promotion measures already mentioned, as well as the elaboration and distribution of educational materials to the population, are essential to the health-disease process of handling the pandemic scenario. Such measures were already advocated by Nightingale as actions attributed to the nurse, a professional responsible for assisting in maintaining vital capacities and meeting the basic health needs of the individual(1,3,8-9).

Nightingale also considered that home was the primary place for interventions aimed at disease prevention, since that was the place where most of the people contracted and suffered from infectious diseases ${ }^{(8-9)}$. Evidence indicates that most of the coronavirus transmissions take place at home and some hygiene practices supposed to be adopted in this environment are crucial to prevent the disease, such as not sharing personal belongings, changing clothes and shoes upon arrival at home, as well as ensuring the immediate social isolation of all confirmed cases, which are among the strategies adopted to contain the spread of the disease by SARS-CoV-2 ${ }^{(1-2,4)}$.

This virus is transmitted from one person to another through respiratory droplets. It has already been found that: among the measures adopted to prevent the spread of the disease is individual behavior, fundamental to delay the transmission of the virus; these measures refer to the care aimed at maintaining a clean and hygienic physical environment, proper hands hygiene, respiratory etiquette (protection of nose/mouth when coughing or sneezing) and use of masks ${ }^{(1-2,4)}$.

Contemporary society faces an environmental crisis, which makes necessary public health policy actions related to epidemiological and health surveillance, relevant to control the spread of the virus and to actions aimed at the diagnosis and treatment of COVID-19 ${ }^{(1-2)}$. Consequently, it is observed that the protective measures of isolation, currently experienced, are the result of these implemented surveillance actions. Likewise, Nightingale was concerned with infection-related care and, therefore, brought concepts of statistics, health surveillance and epidemiology to the infection control, being recognized as a pioneer in this area ${ }^{(8-9)}$.

The solid foundations laid by Florence contribute to the current scenario, by bringing, at that time, as the focus of her theory, the environment that affects life and the development of the organism. Such influences had the capacity to prevent the disease, to suppress it or to contribute to it. That Nightingale knowledge it is very much discussed nowadays ${ }^{(8-9)}$.

In today's global context, those infected with SARS-CoV-2 may be asymptomatic or exhibit moderate symptoms that do not require hospitalization, unlike cases where the symptoms are severe or critical and require medical care in a hospital setting $^{(12)}$. Similarly, during the Crimean War, Florence provided health care for soldiers, and, at that time, it was already given according to the severity of the disease in order to assist those with greater needs and provide the patient with the best conditions for nature to act $^{(8-9)}$.

So far, it has been emphasized the reflections on the association and importance of environmental theory regarding health action practices of promotion, prevention and treatment of COVID-19 directed to patients. In the current pandemic, health professionals have also faced major challenges in dealing with this crisis. It is presumed that they, who deal with patients suspected or confirmed for COVID-19, are vulnerable to high risk of infection, either by the lack of personal protective equipment (PPEs) and guidance to use them, either by poor working conditions in health facilities and/or even by inadequate personal hygiene practices. They often feel fear of infection, fear of spreading the virus to their relatives, which results in the possibility of mental health problems ${ }^{(3,10)}$.

Therefore, it is important to ensure adequate working conditions for those professionals, especially nursing workers, because they are in greater numbers and on the frontline combating the virus. Facing that panorama, different strategies have been adopted with the objective of diminishing the risk to nursing professionals involved in the health care of COVID-19, such as: publications with recommendations directed to safety, guarantee of psychological support through teleconsultation and inspection to verify working conditions in health units in order to protect the professional category and the population ${ }^{(1,3-4)}$.

Despite the strategies mentioned above, there is still devaluation of this professional category, revealed by low salaries, long working hours, and occupational stress, which negatively impacts the health system. This sad reality contrasts with the important role nursing professionals have in contemporary and future society. It is worth mentioning that nursing is a profession with an eye on forms of health production concerning the ethical and legal principles of the health system; and it is based on theories that increasingly consolidate the profession as a science - starting with Nightingale's environmentalist theory, as discussed in this article $e^{(5-7,9)}$.

\section{FINAL CONSIDERATIONS}

Although it was not the Crimean War, a context that allowed Florence to develop her theory, it can be said that the present moment is characterized by a biological war against the coronavirus, a microorganism so potent as weapons used by soldiers on battlefields. That way, it is understood that, even in different contexts, there are similarities as to the fight in the two wars mentioned, both for the maintenance of health and life.

It is believed that the theoretical-scientific background, associated with evidence-based practice, allows the strengthening of combatants, regardless of the established type of conflict. In the case of the Crimean War, the example is soldiers who were healed and emerged victorious. In the current days with the pandemic, the triumph can be observed by the advance of science, in researchers' race in search of a cure, vaccine and treatment for COVID-19, as well as by deep theoretical discussions about the changes generated, in different dimensions of the human being, due to the chaos installed by the pandemic.

It is understandable that, in this battle, there are still many challenges to be overcome, such as ensuring better health conditions for the population and appreciation for the nursing staff job, fighters on the frontline against the pandemic. The quality of health care has been conquered through years of 
confrontation; at the same time, nursing has flourished from a war and, as time went by, to the daily struggles, fight for society's recognition and gradually, through scientific studies in this area, for the meaning of the consolidated profession as a science.

It is known that education can be a great ally for the growth of emotional ties and, consequently, serve to contain a war. It is observed that to save lives, both in the Crimean War and against COVID-19, Florence and other researchers and professionals used their knowledge acquired by studies ${ }^{(7-8)}$.

\section{Contributions to the area}

It is expected that this reflection article can contribute to the construction of the citizen's critical thinking, so that nursing students, professionals and researchers in the field can reflect on the reality and, be able, together with the population, to participate actively in political discussions and thus exercise the social control so important for the public health care decision making and strengthening the Unified Health System (SUS).

\section{REFERENCES}

1. Ministério da Saúde (BR). Protocolo de manejo Clínico do coronavírus (COVID-19) na Atenção Primária à Saúde [Internet]. Brasília - DF: Secretaria de Atenção Primária à Saúde (SAPS); 2020 [cited 2020 Apr 13]. Available from: https://www.saude.gov.br/images/pdf/2020/ marco/20/20200318-ProtocoloManejo-ver002.pdf

2. World Health Organization-WHO. COVID-19 Strategy update [Internet]. Geneva: WHO; 2020[cited 2020 Apr 13]. Available from: https://www. who.int/emergencies/diseases/novel-coronavirus-2019

3. Ministério da Saúde (BR). Saúde mental na Atenção psicossocial na Pandemia COVID-19: recomendações para gestores [Internet]. FIOCRUZ; 2020[cited 2020 Apr 13]. Available from: https://www.fiocruzbrasilia.fiocruz.br/wp-content/uploads/2020/04/Sa\%C3\%BAde-Mental-eAten\%C3\%A7\%C3\%A3o-Psicossocial-na-Pandemia-Covid-19-recomenda\%C3\%A7\%C3\%B5es-para-gestores.pdf

4. Conselho Federal de Enfermagem (Cofen). Cofen publica nota de esclarecimento sobre o Coronavírus (COVID-19) [Internet]. 2020[cited 2020 Apr 13]. Available from: http://www.cofen.gov.br/cofen-publica-nota-de-esclarecimento-sobre-o-coronavirus-covid-19_77835.html

5. Ferreira SRS, Périco LAD, Dias VRFG. The complexity of the work of nurses in Primary Health Care. Rev Bras Enferm. 2018;71 ( suppl 1):704-9. doi: 10.1590/0034-7167-2017-0471

6. Arcêncio RA. Nursing as the profession of the future and the foundation of universal health systems. Rev Latino-Am Enfermagem. 2018;26:e3063. doi: 10.1590/1518-8345.0000.3063

7. Egry EY. Reviewing nursing science: an introduction to reflection. Rev Esc Enferm USP. 2001;35(3):265-70. doi: 10.1590/ S0080-62342001000300010

8. Medeiros ABA, Enders BC, Lira ALBC. The Florence Nightingale's Environmental Theory: a critical analysis. Esc Anna Nery. 2015;19(3):518-24. doi: $10.5935 / 1414-8145.20150069$

9. George JB. Teorias de enfermagem: os fundamentos para a prática profissional. Porto Alegre: Artmed; 2000.

10. Xiang YT, Yang Y, Li W, Zhang L, Zhang Q, Cheung T, et al. Timely mental health care for the 2019 novel coronavirus outbreak is urgently needed. Lancet Psychiatry. 2020;7(3):228-9. doi: 10.1016/S2215-0366(20)30046-8 